\title{
The Use of Indoglish in Faculty of Arts, Udayana University-Bali
}

\author{
I Nyoman Sedeng ${ }^{1}$, Ni Luh Ketut Mas Indrawati ${ }^{2}$ \\ Faculty of Arts - Udayana University \\ Denpasar \\ nyoman_sedeng@unud.ac.id \\ Faculty of Arts - Udayana University \\ Denpasar
}

\begin{abstract}
This study is aimed at 1) identifying the form of linguistic level of Indoglish commonly used in communication in Faculty of Arts, Udayana University Bali; 2) identifying the reasons of speakers when using Indoglish in the campus; and 3) analyzing the impacts of its usage on the speakers Indonesian language. As a source of data, this study uses various forms of authentic conversation that focus on the emergence of Indoglish in Faculty of Arts, Udayana University Bali, which was collected through recording and note taking techniques. In addition, the data was also gathered through filling out questionnaires by 184 respondents consisting of students, lecturers and employees in the faculty. The questionnaires focused more on questions about the respondents' motives behind their using of Indoglish in their communication. The data was then analyzed and presented qualitatively using the theories proposed by Weinrich [1] and Holmes [2].The results of this study indicate that the form of Indoglish linguistic level used in communication between students, lecturers and staff in the Faculty of Arts of Udayana University is at 3 different levels, namely at the word level(71.96\%), the level of the phrase $(12.15 \%)$ and the clause / sentence level(15.89\%; the dominant motives behind the use of the language are to facilitate speaking / convey intentions (34.9\%) and that they do not know the correct interpretation in Indonesian (33.7\%). As many as $16 \%$ of respondents stated that it is for familiarity, $10.9 \%$ to show affirmation intentions, and $1.2 \%$ used the term to express irritation; although most respondents gave a positive response to the impacts of the use of Indoglish together with their Indonesian language, it is still needed to develop a positive attitude towards the use of the correct and appropriate Indonesian in order to optimize the dynamics and poise of the language.
\end{abstract}

Index Terms - linguistic level, indoglish, impact, emergence.

\section{INTRODUCTION}

Indoglish which stands for Indonesian-English is a new language phenomenon that emerges along with the world revolution in technology, information and communication in globalization era. Many experts interpret globalization as the world drown sizing era when people can easily communicate with each other and that distance and time are no longer a barrier. The media social presence, for example, with one of its functions is as an effective and efficient communication media of the period, has brought about much influence in the use of Indonesian language in society which then gives results to the shifts and changes in its structures.

The emergence of Indoglish is actually as the results of borrowing process of English terms by Indonesian speakers. The language is usually used to express English in Indonesian culture, by means that in its use, the English term is still in its original form but its meaning reflects Indonesian language and culture. For examples, the English terms of posting, edit, and browsing are frequently used and heard in Indonesian language communication but are added with 
Indonesian affixes so that the terms become more Indonesian: e.g. memposting, diedit, and browsingan.

There are many factors that have influenced the occurrence of the language. A well-known one is because speakers have difficulties in finding the right equivalent for the English terms they use, and as has been explained above, frequently, they will continue to use the original form and easily add some elements of Indonesian to the term. Another examples the word "men-download" has become common among the Indonesian community in which the process of its formation is very simple that is by adding prefix me $\neg$ - to the English word download to form transitive active sentences. "Orang Indonesia mereproduksi perbedaan semantik yang mereka dapatkan dalam bahasa Inggris, dan mereka akan meminjam dari bahasa Inggris untuk dapat mengekspresikan makna dengan sama tepatnya seperti bahasa Inggris" [3:5]. (Indonesian people reproduce semantic difference that they get from English, and they will borrow the term in order to express the exact meaning as it is in English). However, many studies also reveal that the use of this type of language phenomenon is actually not only as the results of speakers' inadequacy in a language, but is due to a certain motives behind its usage. One of them is for prestige that is speakers usually feel more prestigious when they (intentionally) slip foreign terms in their speech.

In the realm of higher education, especially in Faculty of Arts, Udayana University, the use of Indoglish is commonly heard in everyday communication. This study assumes that in addition to the factors explained above, there must be other reasons behind its usage. The hypothesis of this study is the existence of academic demands due to the emergence of new English terms that have no equivalent in Indonesian may become one of the factors that cause its incidence. This academic condition and situation then has led this study to be conducted which concerns on the factors that has caused Indoglish emergence in university environment, besides, the forms and the effects of its usage in campus.

Based on the background above, this study is aimed to answer the following questions:

1 What are the forms of linguistic level of Indoglish commonly used in Faculty of Arts, Udayana, UniversityBali?

2 What are the reasons of speakers when using the language in campus?

3 What are the impacts of its usage on the speakers Indonesian language?

In order to analyze the data of this study, several theories of word borrowings were used. Holmes [2] stated that borrowing occurs when someone speaks in a second language and includes several terms from his first language, or vice versa. This occurs because of the limitations of the words they have in the second language or because they do not recognize the exact equivalent of the first language. Additionally, Weinreich 1963 [1] asserted that when a word is borrowed into another language, the word changes the mini semantic system, or space where the word acts as a member. In other words when a word is borrowed from another language used in a conversation, all the meanings of the words will adjust to each other.

The borrowing process can occur at the four levels of language, namely: phonology, grammar, vocabulary, and semantic where this allows the occurrence of shifts or even changes in language. According to Susanto [4] the changes in language are commonly interpreted as a change in rules, whether the rules are revised, the rules disappear, or the emergence of a new rule. As a result of the inclusion of foreign words / terms in a language, he added, it would lead to two kinds of changes, namely changes in the form of incoming words in order to adjust to the rules of the recipient's language and changes in the rules of the recipient's language in order to accommodate the elements that come from the outside.

\section{Methodology}

As data source, this study uses various forms of authentic conversations that focus on the emergence of Indoglish in Faculty of Arts, Udayana University. The data was collected through recording and note taking techniques which was done underhandedly in order to get natural as well as trusted data. For this activity stimulus and inducement were provided in an ongoing conversation.

In addition, the data was also collected through filling out questionnaires by 184 respondents consisting of students, lecturers and staff in Faculty of Arts, Udayana University Bali. The questionnaire is in the form of a statements where there are options that could be chosen by the respondents related to the use of Indoglish in academic setting. It is aimed to gather opinions and experiences of respondents in using the language in their campus life.

After the data was collected, they then were transcribed and put into forms classification as well as factors/reasons and impacts of the usage. Finally they were then analyzed and presented qualitatively using the theories as proposed by Weinrich [1] and Holmes [2].

\section{Results AND Discussion}

As has been stated in the background above, the phenomenon of Indoglishin the globalization era is currently unavoidable. Revolution in the field of technology, communication and information is very much felt in the environment of universities where there are many new English terms used in campus life that have not yet have equivalents in Indonesian. Hence, this study is conducted in order to 1) identify the form of linguistic level of Indoglish commonly used in communication in the campus; 2) identify the reasons of speakers when using Indoglish in the environment of the campus; and 3) analyze the impact of the use of Indoglish on Indonesian language in the campus.

This subchapter outlines the results and discussions of 
the problems of this study which cover the forms of linguistic levels of Indoglish that commonly used in Faculty of Arts Udayana University Bali, the reasons of its usage and the effects it is caused to the speakers' Indonesian language.

\section{A. Indoglish Forms of Linguisttic Level Commonly Used in Faculty of Arts, Udayana University-Bali}

From the data collected, there are 107 Indoglish forms obtained from the record of various forms of communication among students, lecturers and employees in Faculty of Arts, Udayana University Bali. The analysis shows that their linguistic levels vary in terms of word level, phrase level and sentence level. There are as many as 77 or $71,96 \%$ of the Indoglish forms are in the linguistic level of word, 13 or $12,5 \%$ are at the level of phrase, and 17 or $15.89 \%$ are at the linguistic level of clause/sentence.

The numbers linguistically show that the tendency to use words turns out to be greater than the tendency to use phrases and clauses or sentences. This indicates that the use of Indoglish is related to the level of language difficulties. A more difficult form of language is not a preference, but a simpler one (i.e. in the linguistic level of word) because it is easy to use. In detail, the linguistic facts that describe the form and linguistic level of Indoglishcan be seen in the following table 1 .

\begin{tabular}{|l|l|}
\hline \multicolumn{1}{|c|}{ CORPUS } & \multicolumn{1}{c|}{$\begin{array}{l}\text { INDOGLISH FORM OF } \\
\text { LINGUISTIC LEVEL }\end{array}$} \\
\hline A: Jangan lupa next week kita ada test & - next week: PHRASE \\
speaking yaa & LEVEL \\
B: Aku prefer writing dari pada speaking & - test : WORD LEVEL \\
sebenarnya nok & - speaking: WORD LEVEL \\
B: Me too but mau enggak mau we must & - speaking: WORD LEVEL \\
to do that & - we must to do that: \\
A: Yes tapi pasti bakal boring & CLAUSE/SENTENCE \\
& LEVEL \\
& - Yes: WORD LEVEL \\
& - Borimg: WORD LEVEL \\
\hline A: Udah buat assignmentnya Mrs. Mas? & - Assignmentnya: WORD \\
B: Yang mana? & LEVEL \\
A: Analysis poetry. & - Oh my god: \\
B: Oh my god, aku lupa. & CLAUSE/SENTENCE \\
Damn. Assignmentnya dikumpul nggak & LEVEL \\
ya? & - Damn: WORD LEVEL \\
\hline A: Biasanya discuss bareng aja kok, tapi & - Discuss: WORD LEVEL \\
aku gak tau gimana kalau yang ini. & - Same with you: \\
B: Kamu udah buat? & CLAUSE/SENTENCE \\
A: Same with you, belum. & LEVEL \\
\hline A: Kok telat bu Kadek? & - Trafficnya: WORD LEVEL \\
B: Trafficnya kuta you know lah & - you know lah: \\
A: Iya sih parah tu. & CLAUSE/SENTENCE \\
& LEVEL \\
\hline A: Udah ada filenya dari Pak? & - Filenya: WORD LEVEL \\
B: Belum lo. Expired datenya kemarin & - Expired datenya: PHRASE \\
lagi & LEVEL \\
A: Searching aja materinya sekarang, & - Searching: WORD LEVEL \\
sebelum ngajar Pak. & \\
\hline A: Kantin yuk, lunch & - Lunch: WORD LEVEL \\
B: Aku stay disini aja deh & - Stay: WORD LEVEL \\
A: Lem me know kalo dosennya udah & - Lemme know: \\
dating ya & CLAUSE/SENTENCE \\
\hline
\end{tabular}

\begin{tabular}{|c|c|}
\hline B: Siap! & LEVEL \\
\hline $\begin{array}{l}\text { A: Eh artikelnya udah disapprove sama } \\
\text { reviewernya? } \\
\text { B: Belum lo baru tadi pagi saya sent lewat } \\
\text { email gatau udah diread atau belum sama } \\
\text { mereka. } \\
\text { A: But I know that mereka pasti lumayan } \\
\text { sibuk sih kayaknya. }\end{array}$ & $\begin{array}{l}\text { - Diapprove: WORD LEVEL } \\
\text { - } \text { Reviewernya: WORD } \\
\text { LEVEL } \\
\text { - } \text { Sent: WORD LEVEL } \\
\text { - } \text { Diread: WORD LEVEL } \\
\text { - } \text { But I know that: } \\
\text { CLAUSE/SENTENCE } \\
\text { LEVEL }\end{array}$ \\
\hline $\begin{array}{l}\text { A: Lagi dimana? } \\
\text { B: On the way nih, dosennya udah dateng? } \\
\text { A: Belumsih, tapi make sure kalau kamu } \\
10 \text { menit lagi kamu udah nyampe yaa. } \\
\text { Dosen kita yang ini selalu on time soalnya. } \\
\text { B: Oke, I'm on my way. }\end{array}$ & 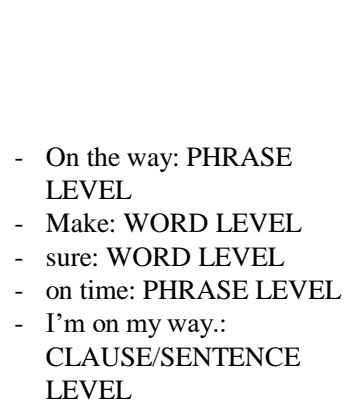 \\
\hline $\begin{array}{l}\text { A: Eeeh kamu jadi ikut maksi bareng kita } \\
\text { di Kansas? Ada menu baru loh ayam } \\
\text { gepreknya tasty banget } \\
\text { B: Sorry banget yaa aku lagi banyak } \\
\text { kerjaan. Sekarang mau bantu ibuku } \\
\text { ngeclean up rumah } \\
\text { A: Aah gakasik } \\
\text { B: Maaf banget ya bro, lain kali aku ikut } \\
\text { hang out bareng kalian. }\end{array}$ & $\begin{array}{ll}\text { - } & \text { Tasty: WORD LEVEL } \\
\text { - } & \text { Sorry: WORD LEVEL } \\
\text { - } & \text { ngeclean up: tatar PHRASE } \\
& \text { LEVEL } \\
\text { - } & \text { hang out: PHRASE LEVEL }\end{array}$ \\
\hline $\begin{array}{l}\text { A: Hey, kamu udah buat tugas } \\
\text { dariMr.Sena? } \\
\text { B: Belum, kamu gimana? } \\
\text { A: Udah. Bukannya dicollect besok ya? } \\
\text { B: Masa? Aku mesti buat sekarangni, } \\
\text { thanks yau dah ngasik tau }\end{array}$ & $\begin{array}{l}\text { - dicollect: WORD LEVEL } \\
\text { - thanks: WORD LEVEL }\end{array}$ \\
\hline $\begin{array}{l}\text { A: Next week yang maju presentasi siapa } \\
\text { guys? } \\
\text { B: Bukannya udah difixin } 5 \text { orang per } \\
\text { pertemuanya? } \\
\text { C: Itu presentasi yang lagi satu, kalau ini } \\
\text { Mrsnya bilang bakal milih random } \\
\text { sebelum presentasi } \\
\text { B: Salah ya hehe } \\
\text { A: Berati presentasi next ini yang majunya } \\
\text { gak sesuai attendance list lagikan? } \\
\text { C: Exactly } \\
\text { A\&B: Okay deh thank you yaa }\end{array}$ & $\begin{array}{ll}\text { - } & \text { Next week: PHRASE } \\
& \text { LEVEL } \\
\text { - } & \text { Difixin: WORD LEVEL } \\
\text { - } & \text { Mrs: WORD LEVEL } \\
\text { - } & \text { Random: WORD LEVEL } \\
\text { - } & \text { Next: WORD LEVEL } \\
\text { - } & \text { attendance list: PHRASE } \\
& \text { LEVEL } \\
\text { - } & \text { thank you: } \\
& \text { CLAUSE/SENTENCE } \\
& \text { LEVEL }\end{array}$ \\
\hline $\begin{array}{l}\text { A: Pulang kerja jadi hangout nih? } \\
\text { B: So pasti jadi } \\
\text { A: Kemana? } \\
\text { B: Level mall atau Plaza renon? } \\
\text { A: Plaza renonaja yuk, saya prefer plaza } \\
\text { renon sih soal nya parker nya rapi its not } \\
\text { kinda like level mall } \\
\text { B: Yuk! }\end{array}$ & $\begin{array}{l}\text { - } \text { Hang out: PHRASE } \\
\text { LEVEL } \\
\text { - } \text { prefer: WORD LEVEL } \\
\text { - } \text { its not kinda like: } \\
\text { CLAUSE/SENTENCE } \\
\text { LEVEL }\end{array}$ \\
\hline $\begin{array}{l}\text { A: Guys presentasi besok withgroup atau } \\
\text { individuya? } \\
\text { B: Group kok } \\
\text { C: Ingetya } 10 \text { menit presentasi } 10 \text { menit } \\
\text { diskusi } \\
\text { A: Oh iya sekarang ada sesidiscussionnya } \\
\text { ya, maksimal berapa questionsih? } \\
\text { B: Maybe 3(tiga) } \\
\text { C: Ya 3(tiga) or 4(empat) pokoknya every } \\
\text { group have } 20 \text { minutes presentasi include } \\
\text { discussion } \\
\text { A: Lumayan lama yah, baiklah, see you } \\
\text { tomorrow, thanks ya informasinya }\end{array}$ & $\begin{array}{l}\text { - Guys: WORD LEVEL } \\
\text { - } \text { With: WORD LEVEL } \\
\text { - } \text { Group: WORD LEVEL } \\
\text { - Discussionnya: WORD } \\
\text { LEVEL } \\
\text { - } \text { Question: WORD LEVEL } \\
\text { - } \text { Maybe: WORD LEVEL } \\
\text { - group have } 20 \text { minutes: } \\
\text { CLAUSE/SENTENCE } \\
\text { LEVEL } \\
\text { - include: WORD LEVEL } \\
\text { - discussion: WORD LEVEL } \\
\text { - } \text { see you tomorrow: }\end{array}$ \\
\hline
\end{tabular}




\begin{tabular}{|c|c|}
\hline & $\begin{array}{l}\text { CLAUSE/SENTENCE } \\
\text { LEVEL } \\
\text { - thanks: WORD LEVEL }\end{array}$ \\
\hline $\begin{array}{l}\text { A: Udah pada liat tugas Mrs. Seri belum? } \\
\text { Udah diupdate tuh jadi udah pada bisa } \\
\text { download } \\
\text { B: Aku udah download kemarin. } \\
\text { Dikumpul minggu depan bukan? } \\
\text { A: Iya next week sent via email } \\
\text { B: Berarti gak perlu print out lagi ya? } \\
\text { A: Iya gak perlu } \\
\text { B: Okay makasi yaa infonya }\end{array}$ & 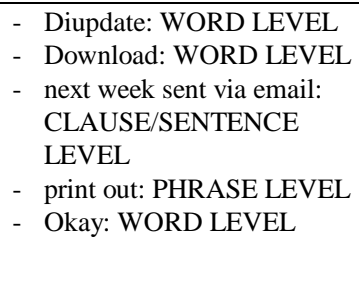 \\
\hline $\begin{array}{l}\text { A: Temans, inget sign di attendance } \\
\text { listnya sebelum pulang yaa } \\
\text { B: Ada yang udah pulang tapi belum ttdni, } \\
\text { gimana? } \\
\text { A: Signin aja dia } \\
\text { B: Kayak gimana? } \\
\text { A: Whatever lah } \\
\text { B: Shit! Okay }\end{array}$ & $\begin{array}{l}\text { - Temans: WORD LEVEL } \\
\text { - Sign: WORD LEVEL } \\
\text { - attendance listnya: } \\
\text { PHRASE LEVEL } \\
\text { - Signin: WORD LEVEL } \\
\text { - Whatever lah: WORD } \\
\text { LEVEL }\end{array}$ \\
\hline $\begin{array}{l}\text { A: Hi, tugas Mr. Arya udah pada buat } \\
\text { belum? } \\
\text { B: Belum nih masih searching di google } \\
\text { A: Kemarin aku juga browsing artikel } \\
\text { tugasnya sih tapi belum nemu juga } \\
\text { B: Emang susah sih materi kali ini. O ia } \\
\text { tugas nya hardcopy atau softcopy? } \\
\text { A: Seingetku hardcopy tapi jaga jaga aja } \\
\text { keduanya } \\
\text { B: Eh aku nemu nih } \\
\text { A: Keywordnya apa? } \\
\text { B: Coba aja cari pemabahasannya dulu } \\
\text { nanti pasti langsung isi contoh } \\
\text { A: Okay deh. Thanks ya }\end{array}$ & $\begin{array}{l}\text { - Searching: WORD LEVEL } \\
\text { - Browsing: WORD LEVEL } \\
\text { - Hardcopy: WORD LEVEL } \\
\text { - Softcopy: WORD LEVEL } \\
\text { - Keywordnya: WORD } \\
\text { LEVEL } \\
\text { - Okay deh: WORD LEVEL } \\
\text { - Thanks ya: WORD LEVEL }\end{array}$ \\
\hline $\begin{array}{l}\text { A: Hey, weekend ini ada rencana mau } \\
\text { kemana ? } \\
\text { B: aku kayaknya bakal ke Cineplex sih } \\
\text { ada film action komedi gitu, and you know } \\
\text { what actornya itu yang jadi Mr. Bean, } \\
\text { pasti filmnya bakal fun banget deh } \\
\text { A: Wah seru tuh aku bisa imagine gimana } \\
\text { kocaknya Mr. Bean di film itu } \\
\text { B: How about you ada plan mau kemana? } \\
\text { A: Kalau aku sih setiap weekend ada } \\
\text { family time gitu terus kayaknya bakal } \\
\text { ngeseafood deh } \\
\text { B: Wah enak tuh seafood } \\
\text { A: tapi honestly aku prefer ayam sih } \\
\text { B: Same with me!!! gak tau kenapa aku } \\
\text { lebih suka ayam juga dari pada yang lain. } \\
\text { One heart ya kita } \\
\text { A: Hahaha iya nih, have fun yaa watching } \\
\text { filmnya } \\
\text { B: Makasi, kamu juga yaa have fun family } \\
\text { timenya, see ya } \\
\text { A: Okay see you }\end{array}$ & $\begin{array}{l}\text { - weekend: WORD LEVEL } \\
\text { - } \text { action: WORD LEVEL } \\
\text { - } \text { actornya: WORD LEVEL } \\
\text { - fun: WORD LEVEL } \\
\text { - } \text { imagine: WORD LEVEL } \\
\text { - How about you?: } \\
\text { CLAUSE/SENTENCE } \\
\text { LEVEL } \\
\text { - Plan: WORD LEVEL } \\
\text { - Family: WORD LEVEL } \\
\text { - Ngeseafood: WORD } \\
\text { LEVEL } \\
\text { - Honestly: WORD LEVEL } \\
\text { - Prefer: WORD LEVEL } \\
\text { - Same with me: } \\
\text { CLAUSE/SENTENCE } \\
\text { LEVEL } \\
\text { - One heart: PHRASE } \\
\text { LEVEL } \\
\text { - Have fun ya watching } \\
\text { filmnya: } \\
\text { CLAUSE/SENTENCE } \\
\text { LEVEL } \\
\text { - Have fun family timenya: } \\
\text { CLAUSE/SENTENCE } \\
\text { LEVEL }\end{array}$ \\
\hline $\begin{array}{l}\text { A: What's going on? } \\
\text { B: Kita lagi discuss assign mentan } \\
\text { alysisnya nih } \\
\text { A: Bakal di presentasiin nggak ya? } \\
\text { C: Power point maksudnya? } \\
\text { A: Iya } \\
\text { C: Dan questionnya sekarang bukan dari } \\
\text { pihak kita tapi dari pihak yang presentasi } \\
\text { A: Harus bener-bener pay attention nih } \\
\text { B: Good luck aja deh buat kita semua }\end{array}$ & 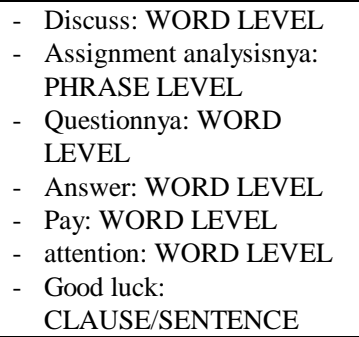 \\
\hline
\end{tabular}

\begin{tabular}{|l|l|}
\hline & LEVEL \\
\hline A: Ada fotocopyan buku baruni yang mau & - Fotocopyan: WORD \\
comment ya & LEVEL \\
B: Wajib nggak? & - Better: WORD LEVEL \\
A: Enggak sih tapi better kamu punya, & \\
mau & \\
B: Boleh deh. Makasi ya & \\
\hline A: sudah pada upload di IMISSU belum? & - Upload: WORD LEVEL \\
B: Eh iya belum, dead linenya kapan? & - Deadlinenya: WORD \\
A: Besok & LEVEL \\
B: oh, ya? & - Uploadin: WORD LEVEL \\
A: Bu Ayu emang belum? & \\
B: Mau minta tolong P wayan buat & \\
uploadin, hehe & \\
A: Beeh & \\
\hline A: Eh ni banyak hasil searchingannya & - Searchingannya: WORD \\
yang mana kamu pilih? & LEVEL \\
B: Yang langsung isi discussionnya aja, eh & - Discussionnya: WORD \\
tapi up to you lah mau pilih yang mana & LEVEL \\
B: Ini ada yang bagus nih & Up to you lah: \\
A: Eh iya save in dong nantik mintak ya & CLAUSE/SENTENCE \\
B: Udah & LEVEL \\
& - Savein: WORD LEVEL \\
& \\
\hline A: Sekalian bookingin saya hotel nya ya & - Bookingin: WORD LEVEL \\
Pak & - Shoppingnya: WORD \\
B: Oke. & LEVEL \\
A: Di Ibis deket malioboro, mau? & \\
B: Boleh. Biar deket shoppingnya, haha & \\
\hline
\end{tabular}

\section{B. The Reasons of Indoglish Usage in Faculty of Arts, Udayana University-Bali.}

A speech is usually present because there is a reason for its use. Regarding the reasons of Indoglish usage in Faculty of Arts, Udayana University-Bali, the data reveals that there are several motives behind the use of the language, namely: to show English proficiency, to facilitate speaking / convey intent, to show the purpose of affirmation, for prestige, because they do not know the correct interpretation in Indonesian, for familiarity, and to express irritation From the observation of the linguistic facts, it is found that the most dominant motive of respondents use the language is in order to facilitate speaking / express their intentions $(34.9 \%)$ followed by the option of because they do not know the correct interpretation in Indonesian $(33.7 \%)$. They commented that when they use the original form of a term, the point of their talking will be fully understood by others. Moreover as they do not know how to express their intent appropriately in Indonesian, they choose to use the original form of English instead.

The other dominant reason of the use is for familiarity. As many as $16 \%$ of respondents stated that they used Indoglish in their conversations is in order to build closeness, relaxed friendliness and intimacy with the interlocutors. Meanwhile, $10.9 \%$ admitted that they used the language to show affirmation of intentions, and $1.2 \%$ using the term to express irritation. Interestingly, different from many studies which believe that prestige becomes the dominant motive of the language used, the data of this study shows that only $2,4 \%$ of the respondents agree to it. The motive is in the 5th rank, right after to affirm attention. Surprisingly, none of the respondents acknowledged that 
using their Indoglish in everyday conversation is to show their English language skills.

C. The impact of using the Indoglish language on the use of Indonesian in the campus of the Faculty of Cultural Sciences, Udayana University

Related to the opinions of the respondents regarding the impact they felt by the use of Indoglish in campus environment the results of the questionnaires analysis show several things as follows:

When respondents were asked about whether Indoglish had a bad impact on the dignity of their Indonesian language, $63.2 \%$ stated "no". They disagree if it is said that the use of Indoglish has negative influences on their Indonesian, and even $83.5 \%$ of them argued that they were not bothered by the presence of the language in their conversations and considered the presence of the language as natural. However, not a few of the respondents (35.1\%) who did not agree if it is said that the existence of the term Indoglish supports the development of Indonesian. They commented that although its use might not have negative impacts on Indonesian language, its presence cannot be said that it supports the development of Indonesian. There seems a fear that its existence will actually reduce the intensity of the use of native Indonesian vocabulary.

Although most respondents gave a positive response to the use of Indoglish in their everyday conversation, however, it is still necessary to develop a positive attitude towards the use of the correct and appropriate Indonesian. If not, it is feared that it will disrupt the dignity of Indonesian language as many people are no longer loyal to the prevailing rules of language, but instead turn to other linguistic forms [3]. Besides, if the use of Indoglish is uncontrolled it mighy hamper the optimization of the dynamics and poise of Indonesian language.

\section{Conclusion}

There are some points that can be concluded from the above analysis as follows:

a. The form of Indoglish linguistic level used in communication between students, lecturers and staff in the Faculty of Cultural Sciences of Udayana University is at 3 different levels, namely at the word level, the level of the phrase and the clause / sentence level

b. The reasons of its using is varied, they are: to make it easier to speak / convey intentions, because they do not know the correct interpretation in Indonesian, for intimacy, for affirmative intentions, and to express resentment

c. Even though most respondents do not feel the negative impact of the use of Indoglish in their Indonesian communication, however, a positive attitudes towards Indonesian language should be more realized.

\section{REFERENCES}

[1] Hassal, T. 2010. Fungsidan Status Kata Pinjaman Barat", dalam Moriyama et al. Geliat Bahasa Selaras Zaman: Perubahan Bahasabahasa di Indonesia Pasca Orde Baru. Jakarta: Kepustakaan Populer Gramedia

[2] Holmes, J. 2013. An Introduction to Sociolinguistics. Wellington: Routledge.

[3] Rahardi, K. R. 2004. Bahasa Indoglish dan Jawanesia dan Dampaknya bagi Permatabatan Bahasa Indonesia. Yogyakarta: Universitas Sanata Darma.

[4] Rakhmawati, A., Saddhono, K., Sri, H., Rio, D. 2016. A Phenomenon OfIndoglish at Universities in Indonesia: Breaking Down the Motives from Sociolinguistics Perspective. Surakarta: Universitas Sebelas Maret. 